\title{
Cloning agenda 'skewed' by media frenzy
}

Erika Check, Washington

As the debate over human cloning in the United States gathers pace, scientists are becoming increasingly concerned that research that has not been peer-reviewed is exerting undue influence on the country's legislators.

Their concern was emphasized at a Senate judiciary committee hearing on cloning held on 5 February. The discussion centred on therapeutic cloning - whether cells from patients should be used to create cloned embryos as a source of stem cells, which could then potentially be grown into replacement tissues perfectly matched to the patient.

At the hearing, Senator Sam Brownback (Republican, Kansas), author of a bill that would ban cloning for any purpose, said that such cloning is unnecessary. His argument was based, in part, on reports that Catherine Verfaillie, a developmental biologist at the University of Minnesota, has grown functional differentiated cells from adult stem cells.

At the same hearing, Brownback's opponent on the issue, Dianne Feinstein (Demo- crat, California), cited a claim that scientists had constructed a kidney from a cloned cow embryo as evidence of the promise of therapeutic cloning.

But neither piece of work has been reviewed or reproduced by other scientists. Such unreviewed claims are cropping up with increasing regularity in policy debates, thanks in part to the rapid dissemination of information on the Internet. This raises the question, researchers say, of whether policymakers know - or want to know - the difference between a claimed result and a peer-reviewed scientific finding.

Verfaillie's work on adult stem cells was described in New Scientist on 26 January. The magazine reported the story on the basis of a patent related to her work.

The cloned-kidney claim first surfaced on 4 December in the Los Angeles Times, when scientists at Advanced Cell Technology (ACT) in Worcester, Massachusetts, told a journalist about the supposed advance. In late January, the claim resurfaced in British and American newspapers.

\section{Share crash puts focus on accounts}

\section{Erika Check, Washington}

The plummeting share price of a leading Irish drug company could lead to closer scrutiny of how such firms account for their research and development spending, analysts say.

Elan, based in Dublin, was until recently the largest company on the Irish stock market, and is also listed on the New York Stock Exchange. Its stock price, which fell from a high of $\$ 63$ last July to $\$ 44$ at the beginning of the year, has dropped by $70 \%$ since then, driven by a number of factors including comparisons of its accounting practices with those of Enron, the failed US energy trading company.

Elan may have stumbled, but it is not about to fall: it reported sales of $\mathbf{\$ 3 5 0}$ million

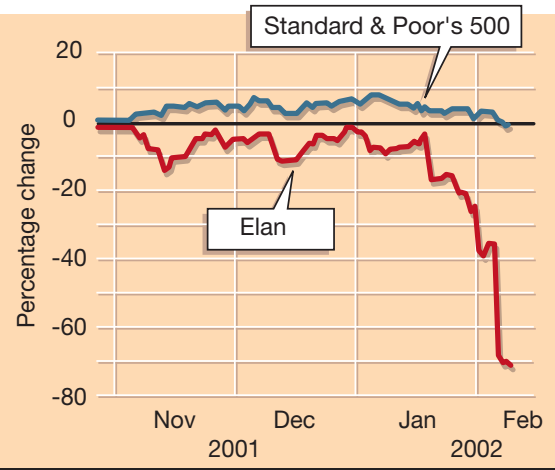

Falling stock: Elan's share price has plunged against the US average since mid-January. last year, and has several products in late-stage clinical trials. "We've got $\$ 2$ billion in the bank and another $\$ 2.4$ billion in marketable securities," says a company spokesman.

But analysts say that Elan's example is a warning to other drug companies that use some of its accounting techniques. According to an investigation published in the Wall Street Journal on 30 January, Elan had set up 55 joint ventures, structured so that it could charge research costs to its partners, instead of counting them as part of its own expenses. It also charged the partners a licensing fee, which Elan counted as income. To wary investors, this set-up looks not unlike that used by Enron to hide its debt.

Analysts say that many drug and biotechnology companies are involved in joint ventures. "If Elan had had five of these it would have been okay," says Ian Sanderson, an analyst at SG Cowen Securities in Boston, "but it had 55 of them generating total revenues of about $\$ 200$ million a year."

Elan's announcement on 18 January that four French patients had become ill during a clinical trial of its drug for Alzheimer's disease (see Nature 415, 462; 2002) initially pushed its stock price down (see chart). This was compounded by disappointing financial results released on 4 February, which included new details about Elan's accounting methods - triggering an investigation by the US Securities and Exchange Commission.

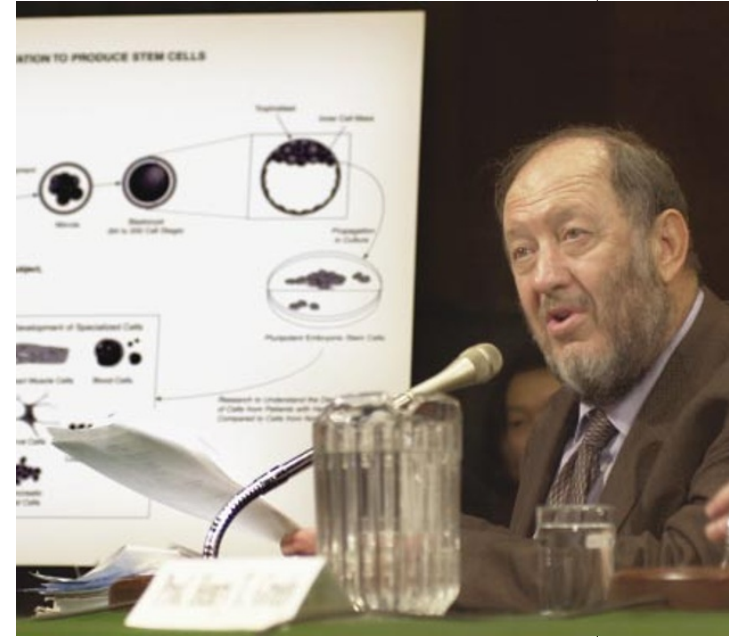

Printed problems: Irv Weissman says that the media 'crossed a line' in the cloning debate.

Stanford biologist Irv Weissman urged senators at last week's hearing to disregard these reports. Indeed, he said, Verfaillie has stated in a letter she sent to legislators that her research should not be used to justify a ban on therapeutic cloning. Researchers will "not know which stem cells, adult or embryonic, are most useful in treating a particular disease without side-by-side comparison of adult and embryonic stem cells," she says in the letter, adding that she supports research into therapeutic cloning.

Although scientists have not questioned the accuracy of Verfaillie's work, they say it would be premature to cease work on embryonic stem cells because it is unclear whether cell lines made from adult stem cells will prove as long-lived or function as well as cell lines made from embryonic tissue.

The ACT work, meanwhile, is of dubious relevance to therapeutic cloning because the cells used to grow the kidney came from an embryo that had been allowed to develop to an early fetal stage. This would be ethically unacceptable if human embryos were used.

Michael West, chief executive of ACT, has apologized for his company's leak of the cow kidney data. "It wasn't intentional," he says.

Nevertheless, scientists are worried that these leaks are unduly influencing the legislative debate. "The fear is that policies will be made based on premature publicity," says Helen Blau, director of the Baxter Laboratory for Genetic Pharmacology at Stanford University.

Researchers have roundly denounced the media for printing unreviewed claims. Weissman says the media "has crossed a line" by printing such reports. But other researchers concede that scientists have a responsibility to refrain from disseminating or commenting on work that has not been peer-reviewed. 